\title{
Transformation from natural (thermal contraction) to anthropogenic (resource exploitation) depressions in the Krotoszyn-Koźmin-Raszków area (Polish Lowland)
}

\author{
Wojciech Stankowski \\ Institute of Geology, Adam Mickiewicz University, ul. Maków Polnych 16, 61-606 Poznań, Poland; \\ e-mail: stawgeo@amu.edu.pl
}

\begin{abstract}
An exceptional concentration of almost identical depressions exist near the small towns of Krotoszyn, Koźmin and Raszków (southern Wielkopolska). Their origin is, however, different from that of the typical post glacial-relief: they are Man-made enlarged thermal-contraction structures that developed at the very end of the Middle Polish (Warthian) glaciation and during the North Polish (Weichselian) glaciation, most probably under periglacial conditions.
\end{abstract}

Keywords: geomorphology, periglacial relief, anthropogenic relief, thermal-contraction structures, Polish Lowland

\section{Introduction}

Small- and medium-sized concave landforms tend to be similar topographically even if they have different origins. Their almost identical morphology makes it commonly difficult for geomorphologists to conclude about their origin. The Polish Lowland is strewn with such endorheic landforms, many of which have a cryogenic, predominantly melt-out, origin. Such depressions are, as a rule, young, dating from postglacial times. However, the areas of the so-called old glacial relief - strongly affected by periglacial conditions, also contain morphologically similar forms, in amounts that differ strongly not only from those that form part of the so-called old glacial morphology, but also from those that are found in the young glacial relief (Fig. 1). In most cases these are not melt- out landforms. They can be due to a wide variety of processes, such as periglacial processes, human activity, and even meteorite impact. An extraterrestrial origin of the depressions in the study area (filled after their formation with carbonates) has been taken into account, but no evidence was found.

Most $(\sim 75 \%)$ depressions in the Polish Lowland have a cryogenic origin (melt-out, postpingo, post-palsa). A second group ( 13\%) consists of basins formed by erosion, dissolution of carbonates, or karst. Other relatively numerous forms $(\sim 2 \%)$ are due to aeolian activity (deflation); these have morphological characteristics that make them relatively easily recognisable. Much less common are the depressions with a cosmic origin, i.e. impact craters $(\sim 0.1 \%)$; their origin is difficult to prove as they quickly undergo denudation, which eliminates 


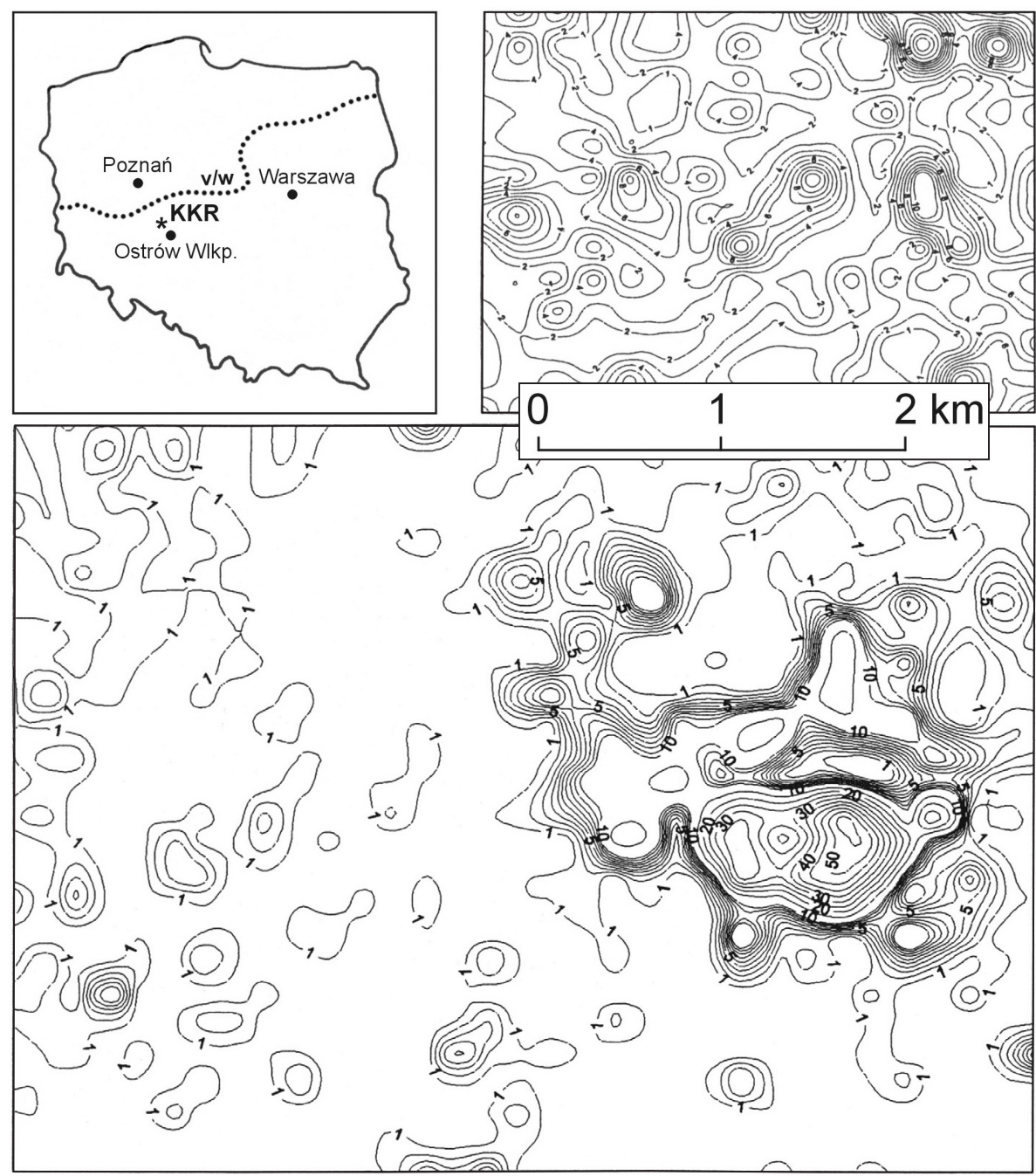

Fig. 1. Location of the study area and the occurrence of small circular pits. A: Location of the Krotoszyn-KoźminRaszków (KKR) area. V/W $=$ maximum extent of the Vistulian/Weichselian ice sheet; B: Concentration of surficial depressions in the vicinity of Gniezno (approx. 40 km E from Poznań); C: Concentration of the pits in the KKR area (at right) compared to their average concentration (left). their diagnostic morphometric characteristics. The recognition of impact craters requires not only detailed field studies, but also specialistic physical-chemical analysis (such as luminescence and radiometric datings), palaeobiological analyses, etc.. Although definite proof of an impact origin thus is difficult, the present author is of the opinion that impact structures are much more numerous than accepted.

In addition to the natural depressions, the relief of the Polish Lowland also contains a number $(\sim 10 \%)$ of anthropogenic depressions, left after exploitation of some natural resource. Such anthropogenic depressions occur, for instance, in the area around the towns of Krotoszyn, Koźmin and Raszków (indicated as 'KKR' in the following), near the town of Ostrów Wielkopolski in central Poland (Fig. 1). Their more or less modern anthropogenic origin is not only confirmed by the local popu- lation (very local more or less circular pits or linear extraction of carbonate deposits used for improvement of the soil), but also by field investigations (Bartkowski, 1949; Krygowski, 1961; Błaszczyk, 1997a,b; Nowacki, 1999a,b; Markuszewska, 2006). The conditions under which the carbonate deposits formed in the denuded and generally decalcified surface of the till plain still needs further study, but here we focus on the origin of the depressions in which the carbonates accumulated. It is therefore important to investigate whether these depressions have an anthropogenic origin in spite of their morphological resemblance to the natural depressions.

The main objective of the present contribution thus is finding out why the carbonates are concentrated in relatively shallow, subcircular and/or linear zones of the strongly decalcified surface of the till-covered plain. 


\section{Morphogenesis and lithology of the study area}

The relief of the Koźmińska Plain, which forms part of the Kaliska Plain (Krygowski, 1956, 1961) developed at the very end of the Warta glaciation, which occurred at the end of the Middle Polish glaciation (equivalent to the Warthe glaciation of the late Saalian). Periglacial processes then occurred. During the last interglacial (Eemian), the relief became more or less stabilised by vegetation, but zones of fluvial erosion developed. During the last 100,000 years, periglacial processes initially dominated the more distant ice-sheet foreland, but they became interrupted by warmer phases since $\sim 30,000$ years ago. Then, during the maximum development of the youngest glacial (Plenivistulian $=$ Pleniglacial $)$ and the Late Glacial, intensive periglacial processes took place, for instance in the form of thermal-contraction structures. The network of cracks and, most of all, the places where these crossed, generated spaces for concentration of the carbonates that resulted from the decalcification of the surface of the till plain.

The glacial and periglacial morphogenesis of the last two glacials affected the area under study and generated vast flat surfaces with mutual differences in heights of 2 (rarely 2.5) $\mathrm{m}$, and an insignificant slope (Błaszczyk, 1997a,b; Nowacki, 1999a,b). The monotonous relief is interrupted by a network of shallow river valleys and small flat-bottomed depressions. The lithology of these depressions is dominated by sandy deposits. The till plains are covered by a nearly continuous layer of glacial till. The top part, usually $0.6-0.8 \mathrm{~m}$ but sometimes up to $1-1.5 \mathrm{~m}$ thick, is decalcified and rich in sand. The lower part contains a more silty/ loamy matrix and is enriched in calcium carbonate (Stankowski, 2001, 2003). At the border between these two parts, which are commonly found in glacial tills, horizons exist where the carbonate contents increases; discontinuous clusters of coarse carbonate grains may even be present.

Such carbonate horizons occur not only in the KKR area, but have also been described from other Great Poland Lowland areas, among others by Kozarski (1995), who described them from the boundary zone at the basis of the permafrost active layer in frozen fluvioglacial deposits. The 'carbonate horizons' in the KKR area are commonly thin, but may occasionally be up to some dozens of centimetres thick. The enrichment in carbonates in the underlying deposits is 'natural' for the area. The degree of carbonate enrichment, both vertically and, particularly, laterally, shows a significant variation, which is controlled by the lithology. The lithological characteristics are, in turn, the result of glacitectonic disturbances of both the Quaternary and the Neogene deposits. The glacitectonic structures are commonly restricted to shallow zone under the surface (Błaszczyk, 1997a,b; Nowacki, 1999a,b). The decalcification of the top part of the till and the enrichment at lower horizons was well illustrated for the Cerabud clay pits at Krotoszyn and Rozdrażew (Sikora-Węncławek, 2006).

\section{Concentric and linear zones of increased carbonate content}

In many sections of the KKR area, numerous clusters of circular and linear pits occur (Fig. 2). They used to be interpreted as 'post-marl pits' of anthropogenic origin (Bartkowski, 1949;

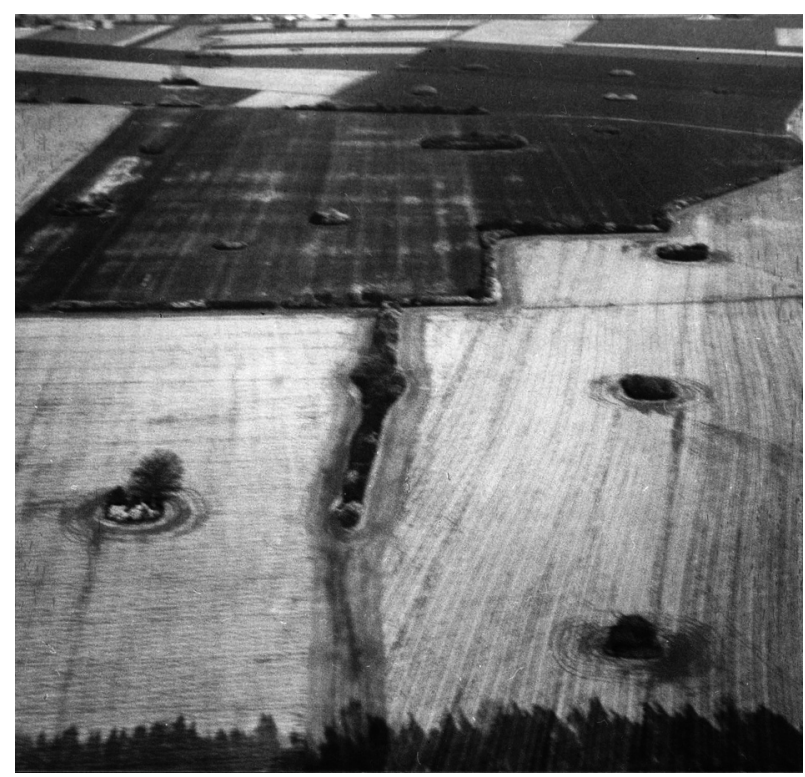

Fig. 2. Aerial photo of part of the KKR area, showing concentric (circular) and linear (elongated) 'post-marl pits'. Photo by R. Derdowski. 
Krygowski, 1961; Błaszczyk, 1997a,b; Nowacki, 1999a,b; Markuszewska, 2006), developed due to extraction of carbonates from the till plain. The commonly present decalcification of the surface sediments and the changes in carbonate content with depth are shown in Table 1. The general trend of different concentrations of carbonate in the sediments of the KKR area is in clear contrast with the common enrichment in carbonates within the circular and linear structures. The walls of the till pit at Rozdrażew reveal decalcification of some glacial tills at various levels as well as significant concentrations of carbonates along relatively thin linear zones (Table 2).

Migration of carbonates in periglacial environments has often been described (Åkerman 1980, 1982; French, 1988; Bukowska-Jania,

Table 1. $\mathrm{CaCO}_{3}$ content of some profiles of glacial till within the KKR area (data obtained jointly by Sikora-Wencławek and the present author).

\begin{tabular}{|c|c|c|c|c|c|c|}
\hline \multirow{3}{*}{ Depth (cm) } & \multicolumn{6}{|c|}{$\mathrm{CaCO}_{3}$ content $(\%)$} \\
\hline & \multicolumn{5}{|c|}{ Profiles } & \multirow{2}{*}{ Mean value } \\
\hline & 1 & 2 & 3 & 4 & 5 & \\
\hline $00-20$ & 2 & 1 & 2 & 3 & 2 & 2 \\
\hline $20-40$ & 3 & 3 & 3 & 3 & 2 & 3 \\
\hline $40-60$ & 4 & 5 & 5 & 4 & 5 & 5 \\
\hline $60-80$ & 6 & 12 & 5 & 4 & 7 & 7 \\
\hline 80-100 & 6 & 15 & 6 & 4 & 7 & 8 \\
\hline $100-120$ & 7 & 12 & 8 & 14 & 9 & 10 \\
\hline $120-140$ & 9 & 10 & 8 & 13 & 10 & 10 \\
\hline $140-160$ & 13 & 7 & 9 & 12 & 9 & 10 \\
\hline $160-180$ & 8 & 6 & 10 & 12 & 8 & 9 \\
\hline $180-200$ & 8 & 6 & 8 & 10 & 7 & 8 \\
\hline $200-220$ & 6 & 5 & 5 & 7 & 6 & 6 \\
\hline $220-240$ & 7 & 8 & 6 & 8 & 7 & 7 \\
\hline
\end{tabular}

Table 2. Spatial and vertical variations in the carbonate content in the glacial till of the clay pit at Rozdrażew $(\sim 10 \mathrm{~km}$ NNE from Krotoszyn, $\sim 6$ km SSE from Koźmin).

\begin{tabular}{|c|c|c|c|}
\hline \multirow[b]{2}{*}{ Depth $(\mathrm{cm})$} & \multicolumn{3}{|c|}{$\mathrm{CaCO}_{3}$ content $(\%)$} \\
\hline & $\begin{array}{l}\text { Decalcification in profile a, } \\
\text { near zone A }\end{array}$ & $\begin{array}{l}\text { Vertical zone of increased } \\
\text { carbonation }(\mathrm{A})\end{array}$ & $\begin{array}{c}\text { Decalcification in profile } \mathrm{b} \text {, } \\
\text { near zone A }\end{array}$ \\
\hline $00-20$ & 0 & 6 & 0 \\
\hline $20-35$ & 0 & 18 & 0 \\
\hline $35-50$ & 0 & 15 & 0 \\
\hline $50-65$ & 0 & 15 & 7 \\
\hline $65-80$ & 0 & 14 & 13 \\
\hline $80-95$ & 0 & 15 & 10 \\
\hline 95-110 & 0 & 20 & 10 \\
\hline $110-125$ & 0 & 11 & 8 \\
\hline $125-140$ & 0 & 15 & 8 \\
\hline $140-160$ & 0 & 11 & 20 \\
\hline $160-180$ & 0 & 10 & 5 \\
\hline $180-200$ & 0 & & 5 \\
\hline $200-220$ & 10 & & \\
\hline $220-240$ & 15 & & \\
\hline $240-260$ & 26 & & \\
\hline
\end{tabular}

Zone $\mathrm{A}$ is a $\sim 8 \mathrm{~m}$ wide vertical zone of two decalticified profiles with a carbonate-enriched zone in between. Data obtained by Sikora-Wencławek. 
2003), and interestingly explained in particular by Kozarski (1995) on the basis of fluvioglacial deposits. The concentration of carbonates down to about $70 \mathrm{~cm}$ does not exceed $\sim 2 \%$. Then it increases: at the depth of $\sim 85 \mathrm{~cm}$ it reaches $\sim 10 \%$ and increases further to $\sim 12 \%$ at a depth of $100-120 \mathrm{~cm}$. Subsequently, it decreases again rapidly to $\sim 4 \%$, i.e. the natural original concentration. Kozarski's findings are similar to the data presented here for the KKR profiles (see Tables 1 and 2).

The genesis of the concentric and linear structures in the KKR region in which carbonates have concentrated is due to periglacial conditions. Exploitation of the carbonates for agricultural purposes (soil improvement) has uncovered a pattern of contraction structures. The study area contains numerous 'post-marl pits', although their present-day network does no longer reflect their original number, because several of these pits have been filled up again and have been transformed into farmland. For- tunately, however, not all structures have been exploited for their carbonate content (see Figs 2 and 3). They illustrate well the primary development of the longitudinal and circular structures on the analysed area. They also reflect the record of natural transformations of the Polish glacial relief under periglacial conditions.

\section{Interpretation}

The detailed analysis of 'post-marl pits' in the KKR area by Maruszewska (2006) led to the conclusion that the pits represent a network of contraction structures. The individual forms as well as the clusters have been subdivided in size categories (up to $49 \mathrm{~m}^{2}, 50-99 \mathrm{~m}^{2}$ and over $100 \mathrm{~m}^{2}$ ). The largest ones were interpreted as places where the main contraction cracks intersect (fig. 4). As a result, the network of structures is very similar to other fossil and contemporarily observed contraction cracks (Fig. 5).

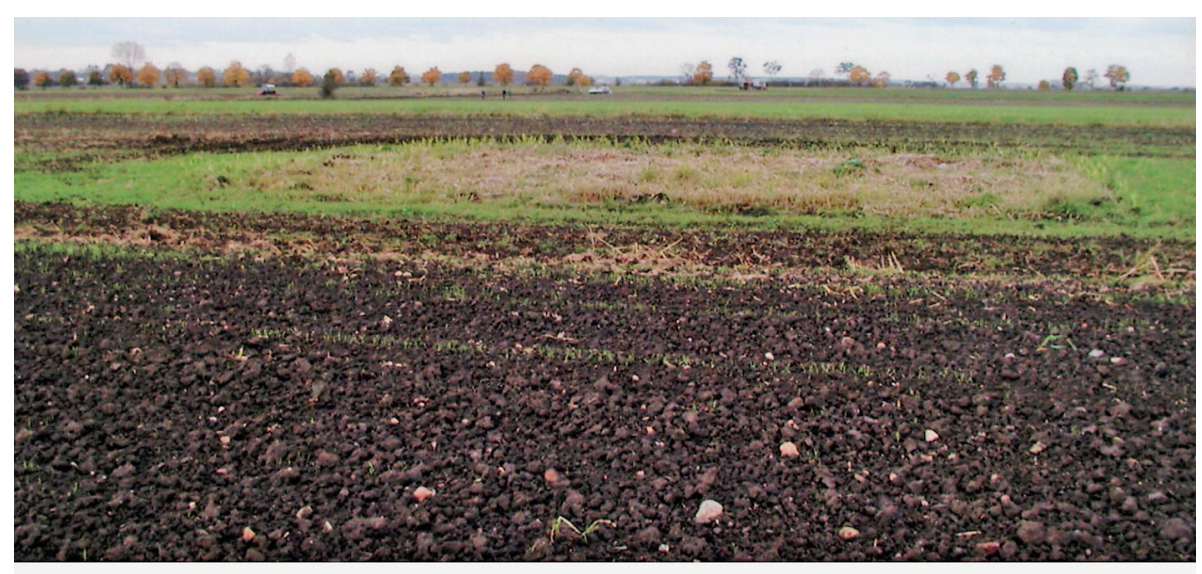

Fig. 3. Non-exploited circular structure filled up with carbonates in the vicinity of Ustków (KKR area).

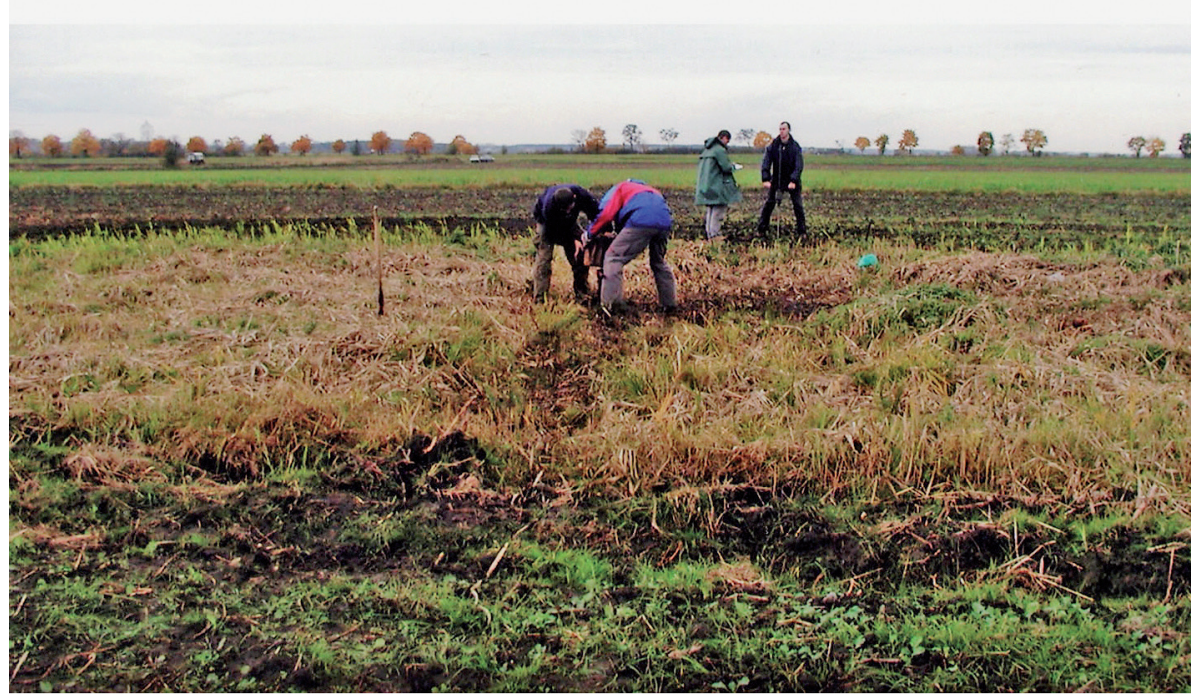



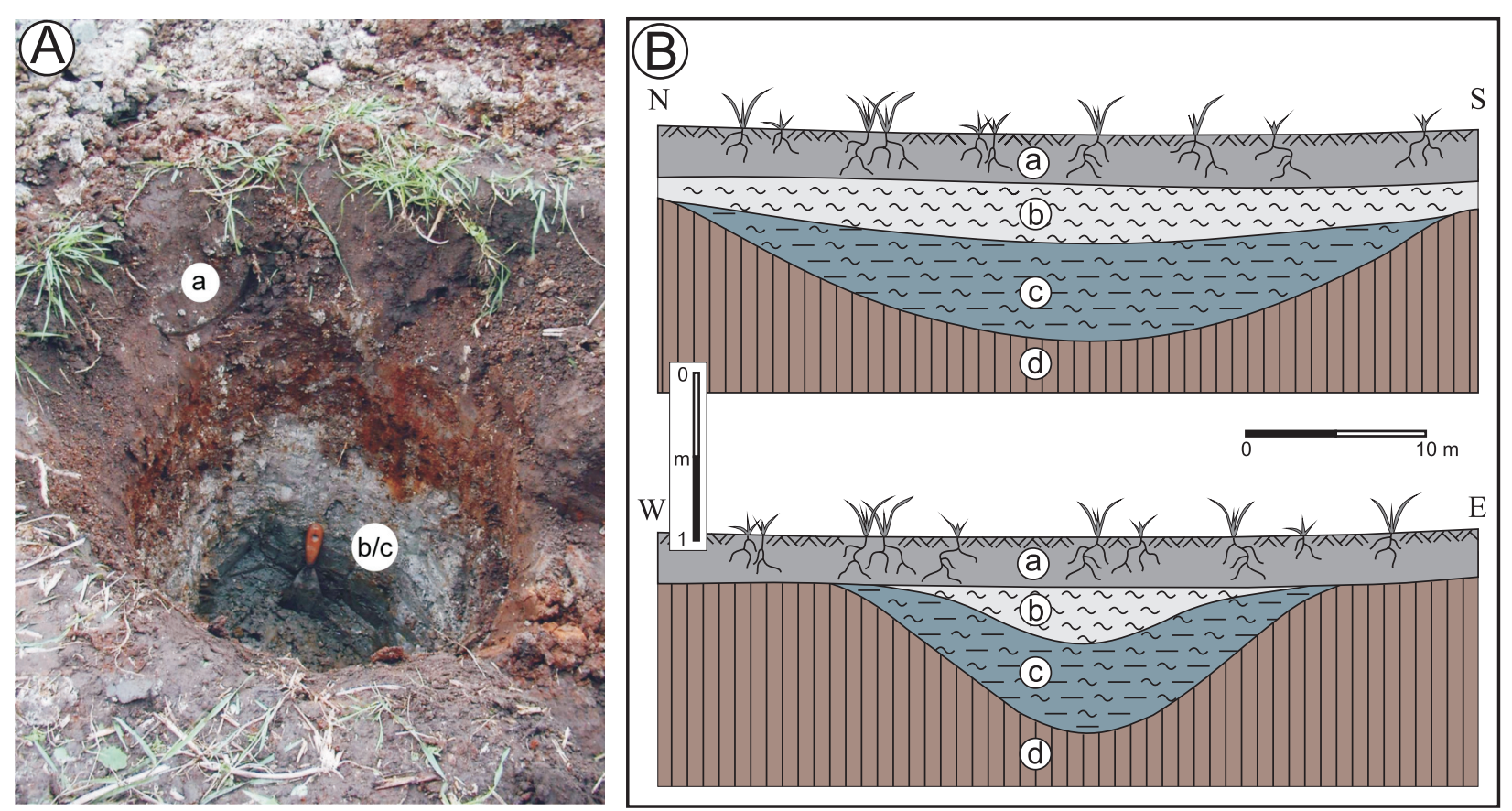

Fig. 4. A: Artificial exposure in a non-exploited pit near Ustków; B: The mutually perpendicular cross-sections indicate the infilling of the depression: $\mathrm{a}=$ humus horizon; $\mathrm{b}=$ calcareous silt; $\mathrm{c}=$ gyttia; $\mathrm{d}=$ till. The cross-sections show the almost symmetrical circular shape and infilling of the depression.

The network of periglacial polygons in the Wielkopolska region, including those related to the last glaciation, is also evident from aerial photos of the area (Bogdański \& Kijowski, 1990). The network of polygons closely resembles contemporary structures on Spitsbergen (Lopez \& Edmaier, 2007). Both the palaeo- and the modern polygonal networks mentioned by Lopez \& Edmaier as well as Bogdański \& Kijowski are presented in Figure 6.

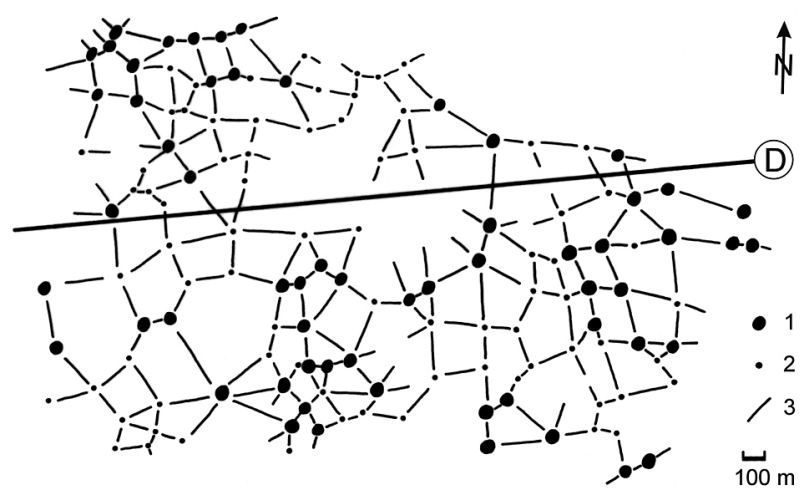

Fig. 5. The network of contraction cracks near Jasne Pole within the KKR area. Data based on Markuszewska (2006). $\mathrm{D}=$ road; 1 = circular depressions of over 50 $\mathrm{m}^{2} ; 2$ = circular depressions $<49 \mathrm{~m}^{2} ; 3=$ interpreted boundaries between the polygons.
The network of pits in the KKR area, represented by wide crack zones and pits with large diameters where the cracks intersect, are thus interpreted as thermal-contraction structures, formed under periglacial conditions. Their sizes are, however, much larger than those of recent periglacial structures (French, 2007) and also significantly larger than the majority of those developed elsewhere in Poland at the end of the last glaciation. This large size must be ascribed to specific hydrogeological conditions and long-term, complex periglacial conditions that allowed such large elongated and circular forms to be created. The large circular pits could form where ice-wedge systems, formed by thermokarst, intersected. In the opinion of the present author, the KKR network probably formed during the periglacial phases of the two last glacials.

\section{Conclusion}

The network of depressions in the KKR area is beyond doubt of anthropogenic origin (cf. Bartkowski, 1949; Krygowski, 1961). They are artificially enlarged thermal-contraction struc- 


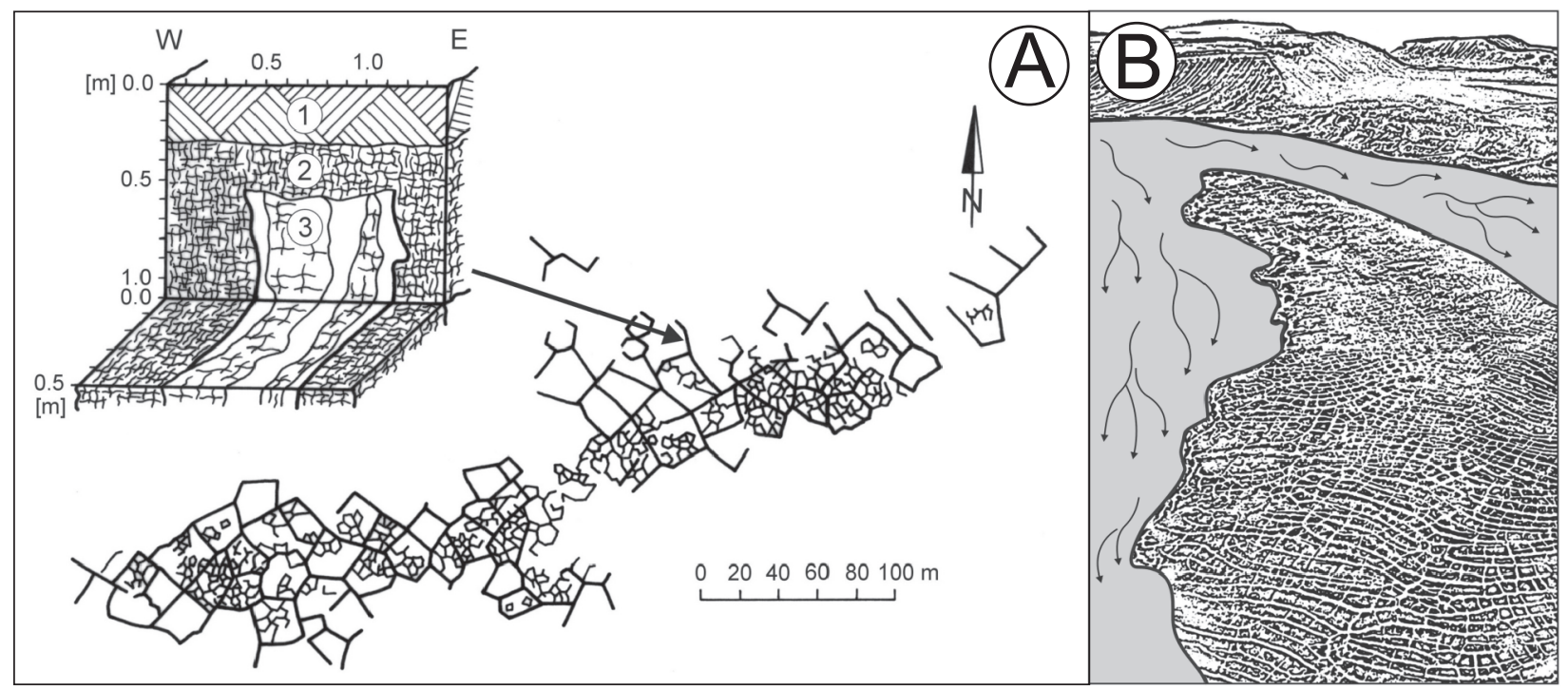

Fig. 6. Pleistocene and modern polygons. A: Network of Pleistocene polygons near Grabinów (after Bogdański \& Kijowski, 1990), showing surface segmentation and a shallow vertical profile: 1 = humus horizon; 2 = decalcified sediments; 3 = elongated carbonate structure; B: Network of modern polygons on Spitsbergen (picture based on a photo from Lopez \& Edmaier, 2007). The schematic sketch shows the network of contraction cracks in an area between two streams.

tures which developed at the end of the Middle Polish glaciation (i.e. Warthian) and during the entire last glaciation. Decalcification of the surface of the till plain under periglacial conditions has led to the increased contents of carbonate infillings of the depressions. These carbonates were exploited during the last dozens of years for improvement of the soil, resulting in new 're-developed' depressions.

\section{Acknowledgements}

The analyses for the present study were supported by the following graduates of Adam Mickiewicz University at Poznań: M. Bednarek (2003), W. Witaszak (2003), A. Wysocki (2003), and K. SikoraWencławek (2006). I would like to thank them for their engagement, reliability and insight. It is why I decided to include exceptionally these works into references. Their input into the present contribution is to be found in their M.Sc. theses of the Institute of Geology of Adam Mickiewicz University.

\section{References}

Åkerman, J., 1980. Studies on periglacial geomorphology in West Spitsbergen. Proceedings of the Geographical Institute of Lund University 89, 150-227.
Åkerman, J., 1982. Studies on naledi (icing) in Western Spitsbergen. [In:] Hydrology in the Permafrost Regions. Proceedings of the 4th Canadian Permafrost Conference, 189-202.

Bartkowski, T., 1949. Z obserwacji nad „oczkami” Równiny Koźmińskiej [Observations of small symmetrical depressions on the Koźmin Plain]. Sprawozdanie Poznańskiego Towarzystwa Przyjaciót Nauk 2, 299-300.

Bednarek, M., 2003. Litologia obszaru Krotoszyn-KoźminRaszków ze szczególnym uwzględnieniem zagłębień bezodptywowych. Okolice miejscowości Łąkociny [Lithology of Krotoszyn-Koźmin-Raszków with special attention for surficial pits. Vicinity of Łękociny]. Institute of Geology, Adam Mickiewicz University, Poznań, 127 pp.

Błaszczyk, J., 1997a. Detailed geological map of Poland 1:50000, sheet Krotoszyn. Polish Geological Institute, Warszawa.

Błaszczyk, J., 1997b. Explanations to detailed geological map of Poland 1:50000, sheet Krotoszyn. Polish Geological Institute, Warszawa.

Bogdański, P. \& Kijowski, A., 1990. Photointerpretation of geometry of Vistulian ice-wedge poligons: the Grabinowo and the Sulejewo sites, south of Poznań. Quaestiones Geographicae 11/12, 39-52.

Bukowska-Jania, E., 2003. Rola systemu lodowcowego w obiegu węglanu wapnia w środowisku przyrodniczym (na przykładzie Svalbardu i młodoglacjalnych obszarów Polski pótnocno-zachodniej [The role of glacier systems in the migration of calcium carbonate in the natural environment, with particular reference to Svalbard and the last-glacial areas in NW Poland]. Silesian University Press, Katowice. 247 pp.

French, H.M., 1988. Active layer processes. [In:] M.J. Clark (Ed.): Advances in periglacial geomorphology. J. Wiley and Sons Ltd, Chichester, 151-177. 
French, H.M., 2007. The periglacial environment ( $3^{\text {rd }}$ ed.). J. Wiley and Sons, Chichester, $458 \mathrm{pp}$.

Kozarski, S., 1995. Deglacjacja północno-zachodniej Polski: warunki środowiska i transformacja geosystemu ( $20 \mathrm{ka}-10 \mathrm{ka}$ BP) [The deglaciation of North-Western Poland: environmental conditions and geosystem transformation $\sim 20 \mathrm{ka}-10 \mathrm{ka} \mathrm{BP})$. Dokumentacja Geograficzna (Wrocław) 1, 47-59.

Krygowski, B., 1956. O dwóch nowych podziałach na regiony geograficzne Niziny Wielkopolsko-Kujawskiej [On two new subdivisions of the Great Poland-Kujawy Lowland into geographical regions]. Badania Fizjograficzne nad Polska Zachodnią 3, 75-112.

Krygowski, B., 1961. Geografia fizyczna Niziny Wielkopolskiej, cz. 1 Geomorfologia [Physical geography of the Great Poland Lowland. Part I, Geomorphology]. T. Bartkowski (Ed.). Poznańskie Towarzystwo Przyjaciół Nauk (Poznań), 184-201.

Lopez, B. \& Edmaier, B., 2007. Zamrożony pejzaż [Frozen landscape]. National Geographic - Polska 12, 85-99.

Markuszewska, I., 2006. Wpływ zagłębień pomarglowych na kształtowanie krajobrazu rolniczego wybranych fragmentów Wysoczyzny Kaliskiej w ostatnim stuleciu [The influence of marl pits on the agricultural landscape of the Kalisz Plain during the last century]. Bogucki Scientific Press, Poznań, 136 pp.

Nowacki, K., 1999a. Detailed geological map of Poland 1:50000, sheet Raszków. Polish Geological Institute, Warszawa.

Nowacki, K., 1999b. Explanations to detailed geological map of Poland 1:50000, sheet Raszków. Polish Geological Institute, Warszawa.Sikora-Wencławek, K., 2006.
Wybrane aspekty litologii osadów czwartorzędowych okolic Krotoszyna [Some aspects of the lithology of the Quaternary sediments in the vicinity of Krotoszyn]. Institute of Geology, Adam Mickiewicz University, Poznań, 87 pp.

Stankowski, W., 2001. 14C and TL dating as a metod of establishing the origin of kettle-like hollows. Geochronometria 20, 103-106.

Stankowski, W., 2003. Kosmogeneza i antropogeneza drobnych zagłębień bezodpływowych [The kosmogenic and anthropogenic origin of small depressions]. [In:] A. Kostrzewski (Ed.) Geneza, Litologia, Stratygrafia Utworów Czwartorzędowych 4, Poznań, 85-88.

Witaszak, W., 2003. Litologia obszaru Krotoszyn-KoźminRaszków ze szczególnym uwzględnieniem zagłębień bezodptywowych. Okolice miejscowości Ustków [Lithology of the Krotoszyn-Koźmin-Raszków area with special attention for surficial depressions. Vicinity of Ustków]. Institute of Geology, Adam Mickiewicz University, Poznań, 95 pp.

Wysocki, A., 2003. Litologia obszaru Krotoszyn-KoźminRaszków ze szczególnym uwzględnieniem zagłębień bezodpływowych. Okolice miejscowości Orpiszew [Lithology of the Krotoszyn-Kozmin-Raszków area with special attention for surficial depressions. Vicinity of Orpiszew]. Institute of Geology, Adam Mickiewicz University, Poznań, 84 pp.

Manuscript received: 25 May 2011 Revision accepted: 15 January 2012 